\title{
Correlation Between Total Ischemic Time with Creatinin Level and Urine Production in Kidney Transplant : A Single Centre Report
}

\author{
Eriawan Agung Nugroho ${ }^{1 *}$, Arif Hidayat ${ }^{2}$ and Ahsanu Taqwim Hidayat ${ }^{2}$ \\ ${ }^{1}$ Division of Urology, Indonesia \\ ${ }^{2}$ Department of Surgery, Indonesia
}

ISSN : 2688-836X

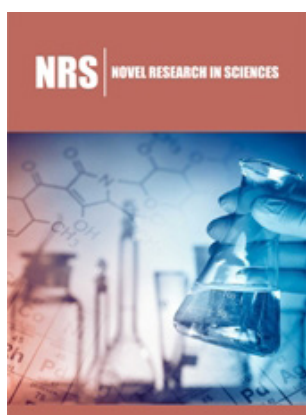

*Corresponding author: Eriawan Agung Nugroho, Division of Urology, Indonesia

Submission: 眥 June 05, 2019

Published: 㓩 June 10, 2019

Volume 1 - Issue 1

How to cite this article: Eriawan A N Arif H, Ahsanu Taqwim H, Govindaraj D K. Correlation Between Total Ischemic Time with Creatinin evel and Urine Production in Kidney Transplant : A Single Centre Report. Nov Res Sci.1(1). NRS.000504.2019. DOI: 10.31031/NRS.2019.1.000504

Copyright@ Eriawan Agung Nugroho, This article is distributed under the terms of the Creative Commons Attribution 4.0 International License, which permits unrestricted use and redistribution provided that the original author and source are credited.

\begin{abstract}
Background: Kidney transplantation is acknowledged as a major advance of modern medicine which provides high-quality life years to patients with irreversible kidney failure (end-stage renal disease, ESRD) worldwide. The first kidney transplantation in Semarang underwent at Telogorejo Hospital in 1985. Dr. Kariadi Hospital nowadays, kidney transplantation had done 28 times since January 2014 until September 2018. Kidney ischemic time is one of the important factor which can affect the outcome of kidney transplantation. The prolonged ischemic of the graft can be related with the effect transplantation. This study is aimed to evaluate the influence of total ischemic time with the outcome of kidney transplantation in Dr. Kariadi Hospital Semarang.
\end{abstract}

Material and Methods: This is an observasional, cross sectional study. The data was collected from medical record. The subject of this study were all patients who underwent kidney transplantation that recorded in medical record from January 2014 until December 2018 and the level of creatinin dan urin production before and after transplantation was documented. There are 28 patient who include in inclusion criteria. The results of the study will be tabulated and statistical calculations are performed using SPSS 23.0. The relationship is declared meaningful if $p=0.05$ is obtained.

Result: From the analysis of the research that has been done using Pearson correlation test and hypothesis test Wilcoxon and it was found that there was a relationship between ischemic time and a decrease in creatinine level from $r=-0.4489$ with a value of $p=0.008$. From the analysis of the research that has been done, there is a relationship between ischemic time and urine production after transplantation with a value of $r=-0.562$ and a value of $p=0.002$

Conclusion: From the results of this study there is a strong correlation between the length of total ischemic time with a decrease in creatinine and urine production which means that the longer ischemic time the lower the decrease in creatinine levels and the less urine production.

Keywords: Total ischemic time; Creatinin level; Urine production; Kidney transplantation

\section{Introduction}

The number of patients diagnosed with end-stage renal disease (ESRD) in indonesia is increasing annualy, showing similiar trend with global prevalence [1,2]. Kidney transplantation is acknowledged as a mayor advance of modern medicine which provides high-quality life years to patients with ERSD worldwide [2,3]. Patient who have kidney transplantation live 10 to 15 years more longer than patient who received dialysis [4].

Since 1985, there were several renal transplantations performed in Telogorejo Hospital and Dr. Kariadi General Hospital, Semarang. In Dr. Kariadi General Hospital Semarang, kidney transplantation had done 26 times since January 2014 until September 2018 [5]. The successful of kidney transplantation is depending on several factor [6,7]. Prolonged ischemic of the graft can be related with the effect transplantation. Ischemic can induced a danger cascade effect that can be worsened with the return of blood supply [8]. This injury can produce inflamatory and immune response that can potentially make delayed kidney function, increased alloimune reactivation, and develompent of progressive pathological change $[9,10]$.

The aim of this study was to investigate the influence of total ischemic time with the outcome of kidney transplantation in Dr. Kariadi General Hospital Semarang. 


\section{Material and Methods}

This is an observational, cross sectional study. The data was collected from medical record of patient who underwent kidney transplantation from January 2014 until December 2018 at Kariadi General Hospital Semarang.

The population in this study is patient with renal failure who had kidney transplantation in Dr. Kariadi General Hospital Semarang. The subject of this study were all patients who underwent kidney transplantation that recorded in medical record from Januari 2014 until December 2018 and the level of creatinin dan urin production before and after transplantation was documented. There are 28 patient who include in inclusion criteria. Descriptive data is presented in the form of tables and box-plots. The normality test use Shapiro Wilk. Then the data was analyzed using the Wilcoxon test. The results of the study will be tabulated and statistical calculations are performed using SPSS 23.0. The relationship is declared meaningful if $\mathrm{p}=0.05$ is obtained.

Result

\section{Creatinine level}

The results of research conducted on 28 study subjects found that before and after transplantation as many as 28 subjects had decreased creatinine (Figure 1). From the analysis carried out obtained creatinine average before transplant $7.9 \pm 2.53$, creatinine mean after surgery $5.2 \pm 4.4$, mean creatinine decrease $3.4 \pm 1.1$ $\mathrm{mg} / \mathrm{dL}$ From the analysis of the research that has been done using Pearson correlation test and hypothesis test Wilcoxon and it was found that there was a relationship between ischemic time and a decrease in renal postin creatinine from $r=-0.4489$ with a value of $\mathrm{p}=0.008$ (Figure 2).

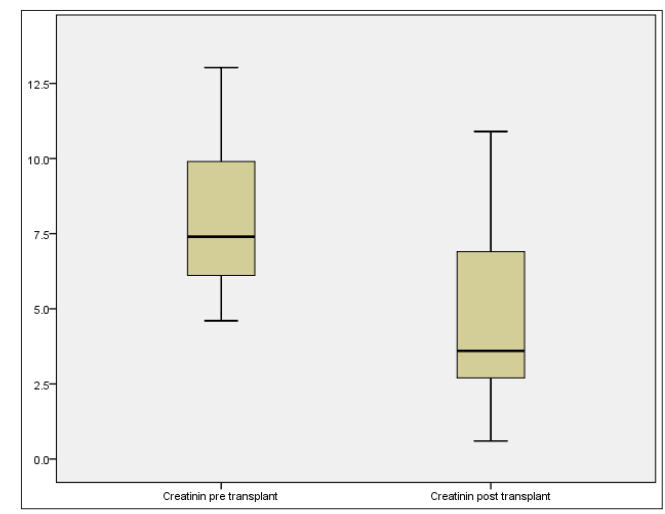

Figure 1: The decreased of creatinin level before and after transplant.

\section{Urine production}

The results of the study conducted on 28 research subjects found that the average urine production 2.5 hours post anastomosis was $294 \pm 87 \mathrm{ml}$. From the analysis of the research that has been done, there is a relationship between ischemic time and post transplant urine production with a value of $r=-0.562$ and a value of $p=0.002$ (Figure 3).

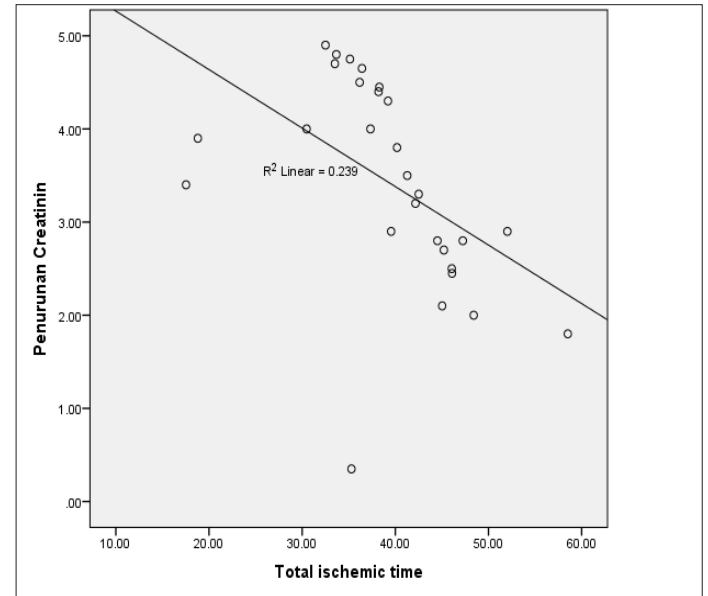

Figure 2: The decreased of creatinine level compared with total ischemic time..

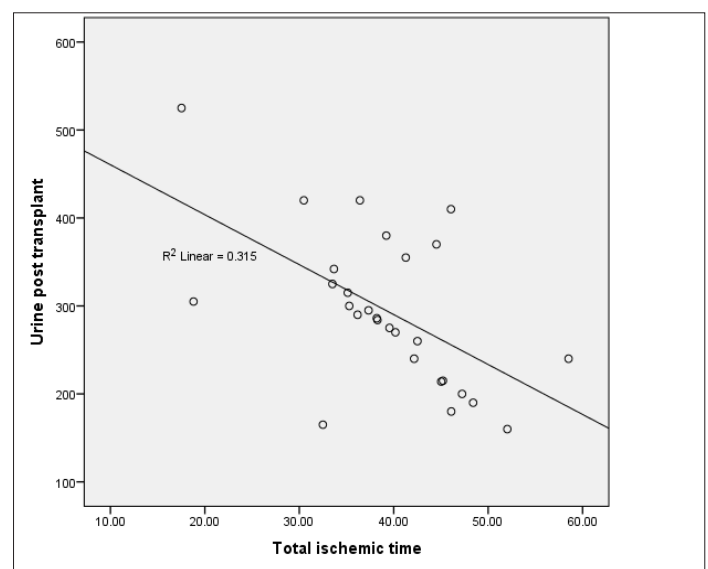

Figure 3: The decreased of urine production compared with total ischemic time..

\section{Discussion}

Chronic kidney disease (CKD) is a damage to the structure or function of the kidney lasting $\geq 3$ months, with or without a decrease in glomerular filtration rate (GFR) [11]. The succesfull of kidney transplantation is depending on some factor such as ischemic time [6,7]. Total ischemic time is defined as the time of the donor renal artery interruption or aortic clamp, until the time of release the clamp on the renal artery in the recipient (in hours). Total ischemic time is a combination of cold ischemic ime (CIT) and warm ischemic time (WIT) [12,13]. polonged ischemic time is associated with increase of Delayed graft function (DGF) and longer length of stay which consequently increase the cost of transplantation $[14,15]$.

Reperfusion after CIT activates the complex cascade, which ultimately contributes to apoptotic or necrosis cell death. This phenomenon is also known as Ishemic Reperfusion Injury (IRI) [8]. It is known that injuries caused by ischemia and reperfusion and to some extent also with cooling and rewarming give rise to cascades which ultimately leads to apoptosis, endothelial cell injury, and activation of the innate immune response resulting from organ dysfunction [10]. 
DGF occurred in $13.5 \%$ of recipients with a total ischemic time of 14 hours or longer than $10.9 \%$ of those with shorter ischemic time. This effect is greatest for those with donors aged 55 years or more. thus, appears that the consequences of a long ischemic time are mainly identifiable in the early posttransplant period as DGF and possibly an increased acute rejection rate. The effects of ischemic time on the long-term outcome of renal transplantation in the forms of impaired graft function and graft survival are less evident $[10,16]$.

\section{Conclusion}

From the results of this study there is a strong correlation between the length of total ischemic time with decrease in creatinine levels and urine production which means that the longer ischemic time the lower the decrease in creatinine levels and then less urine production.

\section{Acknowledgment}

The author would like to say thank you, to editorial board and all staff Renal Transplant Team Dr. Kariadi General Hospital Semarang, for support this research.

\section{References}

1. Projosudjadi W (2006) Incidence, prevalence, treatment and cost of end-stage renal disease in indonesia. Ethn Dis 16(Suppl 2): S2-14-16.

2. Hill NR, Fatoba ST, Oke JL, Hirst JA, O Callaghan CA, et al. (2016) Global prevalence of chronic kidney disease- asystematic review and metaanalysis. PLoS One 11: e0158765.

3. Perhimpunan Nefrologi Indonesia (2013) Jakarta: konsensus transplantasi ginjal perhimpunan nefrologi Indonesia.

4. Dina-Nilasari, Haerani-Rasyid, Marbum MBH (2015) Konsensus evaluasi donor dan resipien transplantasi ginjal serta penatalaksanaan perioperatif. Medicinus 28: 45-55.

5. Supit T, Nugroho EA, Santosa A, Soedarso MA, Daniswara N, et al. (2019) Kidney transplantation in Indonesia: an update. Asian J Urol.

6. Campbell S, Pilmor H, Gracey D, Mulley W, Russel C, et al. (2013) HKHA-
CARI guideline: recipient assessment for transplantation. Nephrology 18: $455-462$.

7. Kayler L, Kang D, Molmenti E, Howard R (2010) Kidney transplant ureteroneocystostomy techniques andcomplications: review of the literature. Transplant Proc 1413-1420.

8. Cavaillé-Coll M, Bala S, Velidedeoglu E, Hernandez A, Archdeacon P, Gonzalez G, et al. (2013) Summary of FDA workshop on ischemia reperfusion injury in kidney transplantation. Am J Transplant 13: 11341148.

9. Debout A, Foucher Y, Trébern-Launay K, Legendre C, Kreis H, et al. (2015) Each additional hour of cold ischemia time significantly increases the risk of graft failure and mortality following renal transplantation. Kidney Int 87: 343-349.

10. Ponticelli CE (2018) The impact of Cold Ischemic time on renal transplant outcome. Kidney International 87(2): 272-274.

11. National Kidney Foundation (2002) K/DOQI clinical practice guidelines for chronic kidney disease: evaluation, classification and stratification.

12. Wong G, Teixeira A, Chapman JR, Craig JC, Pleass H, et al. (2017) The impact of total ischemic time, donor age and the path-way of donor death on graft outcomes after deceased donor kidney transplantation. Transplantation 101: 1152-1158.

13. Vinson AJ, Rose C, Kiberd BA, Odutayo A6, Kim SJ, et al. (2018) Factors associated with prolonged warm ischemia time among deceased donor kidney. Transplant Recipients. Kidney transplantation 4(5): e342.

14. Serrano OK, Vock DM, Chinnakotla S, Dunn TB, Kandaswamy R, et al. (2019) The relationships between cold Iichemia time, kidney transplant length of stay, and transplant-related costs. Transplantation 103(2): 401-411.

15. Nugroho EA, Kamar MA, Junita D (2019) The correlation between total ischemic time with lenght of hospitalization in kidney transplantation: A single centre report. Internat J Sci Eng vol 13(1): 28-23.

16. Adam Van DV, Warle MC (2013) The need to reduce cold ischemic time in kidney transplantation. Curr Opin Organ Transplant 18: 174-178. 